http://dx.doi.org/10.4314/jae.v19i2.7

\title{
Perceived Role Achievement and Role Expectation of Local Government Agricultural Programmes in Southeast, Nigeria
}

\author{
Mgbenka, R. N. \\ E-mail: amakamg@yahoo.com \\ Department of Agricultural Extension, Faculty of Agriculture, \\ University of Nigeria, Nsukka, Nigeria
}

\author{
Igbokwe, E. M. \\ E-mail: emigbo@yahoo.com \\ Department of Agricultural Extension, Faculty of Agriculture, \\ University of Nigeria, Nsukka, Nigeria \\ Chah, J. M. \\ E-mail: \\ Department of Agricultural Extension, Faculty of Agriculture, \\ University of Nigeria, Nsukka, Nigeria
}

\section{Abstract}

The study ascertained agricultural development role expectations and role achievements among local government authorities (LGAs) in southeast, Nigeria. Some LGAs in the study area contributed to the success of some agricultural programmes in different ways such as providing training facilities at local government (LG) and farmers' levels. However, some assessment studies on the effectiveness of LGAs' agricultural activities in southeast, Nigeria show unfavourable reports on the achievements of specified agricultural roles such that rural farmers still experience low agricultural productivity. Questionnaire and interview schedule were used to collect data on agricultural role expectation and role achievement of LGAs from 179 LG staff members and 145 farmers using multistage sampling. Data were analysed using mean score, standard deviation and students' t-test. The mean scores for farmers on role expectation were, for provision of water scheme (2.7), market gardens (2.7), and tractors (2.5). Those of LG staff were for provision of water scheme (2.3), market gardens (2.3), and tractors (2.2). The mean scores for farmers on role achievement by LGAs with respect to provision of processing plants and bore-holes were 2.1 and 2.3, while those of LG staff were 3.7 and 4.1, respectively. There were significant differences between LG staff and farmers' perception on expected agricultural roles ( $t=$ 2.9; $p \leq 0.05)$ and role achievement (t=18.0; $p \leq 0.05)$ of LGAs. The study recommends representation of farmers in LGs' agriculture department to enhance planning of agricultural interventions that will address farmers' felt needs.

Keywords: Local governments, role expectations and role achievements, southeast, Nigeria. 


\section{Introduction}

Local governments (LGs) in Nigeria according to the 1976 Guidelines is defined as legally established representative council empowered to initiate and direct the provision of services and to determine and implement projects so as to complement the activities of the State and Federal governments in their areas. It is a government at the grassroots of administration meant for meeting peculiar needs of the people at grassroots. A LGA should have a population range of 150,000 to 800,000 . In creating the LGs, the government focuses on the administration of the public at the grassroots where there is a majority of the population of Nigeria.

It was the belief of the founders of LGAs in Nigeria therefore that Nigeria will develop only when the rural communities are developed. This will only happen when the administrators are committed to the development of the communities. According to Madukwe (2008) LGs are established worldwide to facilitate local development which could be economic, social and political. Local government as the third tier of government brings agricultural interventions to the rural farmers. The functions of a LGA in the area of agriculture as contained in the Fourth Schedule, Section 7 of the 1999 Constitution include establishment, maintenance and regulation of slaughter houses, slaughter slab, markets, market gardens, parks; and participation in the development of agriculture and natural resources, other than the exploitation of minerals. According to Manyong, et. al. (2005), the federal government also hoped to provide through LGAs the following services in local government areas (LGAs): (1) the provision of an effective extension service; (ii) provision of rural infrastructure to complement federal and state governments' efforts; (iii) management of areas irrigated with dams; (iv) mobilization of farmers for accelerated agricultural and rural development through cooperative organizations, local institutions, and communities; (v) provision of land for new entrants into farming in accordance with the provision of the Land Use Act; and (vi) coordination of data collection at primary level.

With unfavourable reports about the performances of LGAs in agricultural development, it is apt to examine the present strength and weaknesses of LGAs towards the implementation of national agricultural policy as listed above. The study therefore ascertained role expectations of agricultural department as perceived by LG staff and farmers and determined role achievement of agriculture department as perceived by LG staff and farmers in different states in southeast, Nigeria. The choice of LG staff and farmers as respondents for this study was on the basis that LGAs have stipulated agricultural roles by the federal government; farmers are the direct beneficiaries of these agricultural services.

To this effect, the following null hypotheses were tested: 
(i) There is no significant difference between LG staff and farmers' responses on the role expectation of LGAs in agricultural development.

(ii) There is no significant difference between LG staff and farmers' responses on the role achievement of LGAs in agricultural development.

\section{Methodology}

Quantitative approach (key informant interviews, structured and semistructured interview schedules) were used to collect data from 324 responses using multistage sampling procedure. Secondary data were collected from annual budget and expenditure profiles of the LGAs. In the first stage, four states (Abia, Anambra, Ebonyi and Enugu) were randomly selected from the five states (Abia, Anambra, Ebonyi, Enugu and Imo) that make up southeast Nigeria. In the second stage, five LGAs were purposively selected from each of the four states based on their past participation on agricultural programmes such as Fadama III project, etc. In the third stage, four town communities were randomly selected from each LG giving a total of 80 . Two farmers were randomly selected from each town community giving a total of 160 farmers. One management staff (head, agriculture unit) and the chairman of each of the 20 LGCs were purposively selected for the study giving a total of 40 . The purposive selections were based on their being in the better positions to provide information as regards agricultural development in their LGs. From each of the 20 LGs selected, 14 staff were randomly selected to give a total of 280 staff. The total sample size for the study was therefore 480 respondents. However, only 145 farmers and 179 LG staff out of respondents earmarked for the study were assessable.

Four point, five point and three point Likert- type scales were used to measure role expectation, role achievement and factors inhibiting role performance of LGAs, respectively. Decision points of the mean scores were $\geq 2.5,3.0$ and 2.0 , respectively. The mean scores for role expectation, role achievement and factors inhibiting role performance of LGAs were determined for the farmers and LG staff.

\section{Results and Discussion}

\section{Role expectation of LGAs in agricultural programmes}

Both LG staff $(\bar{x}=2.6)$ and farmers $(\bar{x}=2.9)$ indicated that LGCs were expected to procure and distribute agricultural inputs such as fertilizer (Table 1). Okenwa (2009) reports that procurement of farm inputs for farmers is one of the agricultural roles of LG. An oral interview with some of the HODs of Agriculture/Veterinary Department of LGs confirmed the finding. This implies that both LG staff and farmers were aware of the roles of the LGs. Other roles included mobilization of farmers to form cooperatives and formation of farmer community associations (LG staff; $\bar{x}=3.0$ and farmers, $\bar{x}=3.3$ ), provision of 
animal health extension services (LG staff; $\bar{x}=2.5$ and farmers; $\bar{x}=2.6$ ), etc. Provision of effective extension service, provision of rural infrastructure, mobilization of farmers for accelerated agricultural and rural development through cooperative organizations, local institutions and communities were the roles stipulated by Nigerian Agricultural Policy of 2001. These roles are similar to those stipulated by Nigerian Agricultural Policy of 2001 and those stated by Okenwa (2009). This implies that the respondents have good knowledge of the LGs' roles. Akinsuyi (2011) also listed roles of LGs and advocates that LGAs should be aware of their roles in agricultural development for better achievement of these roles. Therefore, if LGAs play their roles, the dream of self-sufficiency in food production could be a reality.

The following roles were perceived by only farmers as LGAs' roles: provision of water bore-hole $(\bar{x}=2.6)$, provision of veterinary clinics $(\bar{x}=2.6)$, provision of market gardens $(\bar{x}=2.7)$ and provision of tractors and implements $(\bar{x}=2.5)$. The roles stated by farmers are in agreement with Nigerian Agricultural Policy of 2001 stipulated roles of LGs. The farmers were aware of their needs and the ones that the LGs can provide for them. 


\section{Table 1: Role expectations of LGCs' agricultural departments as perceived by LG staff and farmers}

\begin{tabular}{|c|c|c|c|c|c|}
\hline \multirow[t]{2}{*}{ Role } & \multicolumn{2}{|c|}{ LG staff } & \multicolumn{2}{|c|}{ Farmers } & \multirow[t]{2}{*}{ t-value } \\
\hline & $\overline{\bar{x}}$ & SD & $\overline{\bar{x}}$ & SD & \\
\hline Provision of agricultural extension services & $2.7^{*}$ & 1.3 & $3.1^{*}$ & 3.3 & -1.5 \\
\hline Provision of animal health extension services & $2.5^{*}$ & 1.3 & $2.6^{*}$ & 1.1 & -1.1 \\
\hline Control and acquisition of land for new entrants into farming & 2.3 & 1.2 & 2.4 & 1.1 & -0.1 \\
\hline Provision of road network or good feeder roads & $2.6^{*}$ & 1.4 & $2.7^{*}$ & 1.1 & -0.8 \\
\hline Provision of processing plants & 2.1 & 1.3 & 1.9 & 1.4 & 1.4 \\
\hline Provision of storage facilities & 2.1 & 1.4 & 2.2 & 1.4 & -0.9 \\
\hline Provision of transport and communication facilities & 2.0 & 1.4 & 2.4 & 1.4 & $-2.5^{\star *}$ \\
\hline Provision of water scheme-borehole & 2.3 & 1.4 & $2.6^{*}$ & 1.3 & $-2.2^{* *}$ \\
\hline Provision of schools & $2.5^{\star}$ & 1.4 & $2.9^{*}$ & 1.3 & $-2.2^{* *}$ \\
\hline Provision of veterinary clinics & 2.4 & 1.4 & $2.6^{*}$ & 1.3 & -1.9 \\
\hline Provision of markets & $2.6^{*}$ & 1.4 & $3.1^{*}$ & 1.1 & $-2.9^{\star *}$ \\
\hline Provision of slaughter houses and slabs & $2.7^{*}$ & 1.4 & $3.1^{*}$ & 1.0 & $-2.8^{* *}$ \\
\hline Provision of motor parks & $2.5^{\star}$ & 1.4 & $3.0^{*}$ & 1.1 & $-2.2^{* *}$ \\
\hline Provision of market gardens & 2.3 & 1.4 & $2.7^{*}$ & 1.2 & -0.9 \\
\hline Establishment of demonstration plots & 2.1 & 1.4 & 2.4 & 1.3 & \\
\hline Mobilization of farmers to form cooperatives and formation of farmer communities & & & & & \\
\hline associations & $3.0^{*}$ & 1.2 & $3.3^{*}$ & 3.4 & $-1.9^{\star *}$ \\
\hline Procurement and distribution of agricultural inputs such as: & & & & & \\
\hline $\begin{array}{l}\text { Fertilizers } \\
\text { Agro-chemicals such as herbicides, etc. }\end{array}$ & $2.6^{*}$ & 1.5 & $2.9^{*}$ & 1.3 & 0.6 \\
\hline Improved seeds & 2.2 & 1.6 & 2.1 & 1.5 & -0.1 \\
\hline Improved seedlings & 2.2 & 1.4 & 2.2 & 1.5 & -1.2 \\
\hline Improved breeds of livestock & 2.2 & 1.4 & 2.3 & 1.4 & -1.6 \\
\hline Provision of veterinary drugs and vaccines & 2.1 & 1.4 & 2.4 & 1.4 & 0.2 \\
\hline Provision of tractors and implements & 2.3 & 1.4 & 2.3 & 1.4 & $-2.2^{\star *}$ \\
\hline $\begin{array}{l}\text { Promotion of viable agro-based projects such as snail, fish and poultry farming } \\
\text { Creation of awareness through exhibition of agricultural products, shows, tree }\end{array}$ & 2.2 & 1.5 & $2.5^{\star}$ & 1.3 & -1.1 \\
\hline $\begin{array}{l}\text { planting field days etc. } \\
\text { Participation and coordination of agriculture development projects and programmes }\end{array}$ & $2.8^{*}$ & 1.3 & $3.2^{*}$ & 4.7 & $-1.9^{\star *}$ \\
\hline $\begin{array}{l}\text { at local levels } \\
\text { Rural youth and women training on various agriculture enterprises }\end{array}$ & $2.8^{*}$ & 1.3 & $3.0^{*}$ & 1.2 & -1.2 \\
\hline Provision of agriculture staff training and workshops & $2.8^{*}$ & 1.3 & $3.2^{*}$ & 3.3 & -1.2 \\
\hline Provision of health centres and clinics & $2.7^{*}$ & 1.4 & $2.8^{*}$ & 1.2 & $-2.7^{\star \star}$ \\
\hline Overall t-test & $\begin{array}{l}2.5^{*} \\
2.2\end{array}$ & $\begin{array}{l}1.5 \\
1.6\end{array}$ & $\begin{array}{l}2.9^{*} \\
2.4\end{array}$ & $\begin{array}{l}1.4 \\
1.7\end{array}$ & $\begin{array}{l}-1.0 \\
-2.9^{\star \star}\end{array}$ \\
\hline
\end{tabular}

${ }^{*}=$ expected roles $(\bar{x}=\geq 2.5)$

It is surprising that some important roles such as control and acquisition of land for new entrants into farming (LG staff; $\bar{x}=2.3$ and farmers; $\bar{x}=2.4$ ), provision of processing plants (LG staff; $\bar{x}=2.1$ and farmers; $\bar{x}=1.9$ ), etc. were not recognized by respondents as roles of LGAs in agricultural development. This could be as a result of ignorance which will definitely hamper their performance. Many of the roles not recognized as the roles of LGAs were stipulated by Nigerian Agricultural Policy of 2001 and constitution amendments. 


\section{Differences in role expectation of LGAs in agricultural programmes as perceived by LG staff and farmers}

There were significant differences ( $\mathrm{t}=-2.9)$ in the perception of $L G$ staff and farmers on some agricultural roles of the LGAs. (Table 1). Provision of tractors and implements $(\mathrm{t}=-2.2)$, provision of water bore-hole $(\mathrm{t}=-2.5)$, provision of schools ( $\mathrm{t}=-2.2)$, provision of markets gardens $(\mathrm{t}=-2.8)$, provision of slaughter houses ( $\mathrm{t}=-2.9)$, among others were some of the roles perceived differently by LG staff and farmers as expected roles of LGAs. The significant difference in more than half of the roles (as farmers had higher expectations than LG staff) shows high variation in the opinions of the two groups. This implies that there is a big gap in the understanding of the two groups of respondents about the agricultural roles of LGAs. This could be probably because farmers expected LGAs to provide the required agricultural services. 


\section{Perception of LG staff and farmers on role achievements of LGs in agricultural programmes}

Local government staff of agriculture/veterinary department and farmers indicated that nine out of 28 roles presented were accomplished by LGCs (Table 2). Some of the roles were provision of agricultural extension services (LG staff; $\bar{x}=4.0$ and farmers; $\bar{x}=3.1$ ), provision of fertilizers (LG staff; $\bar{x}=4.2$ and farmers; $\bar{x}=3.2$ ), provision of road network (LG staff; $\bar{x}=4.2$ and farmers; $\bar{x}=3.1$ ), mobilization of farmers to form cooperatives and formation of farmer communities associations (LG staff; $\bar{x}=4.4$ and farmers; $\bar{x}=3.0$ ), creation of awareness through exhibition of agricultural products, shows, tree planting field days etc. (LG staff; $\bar{x}=4.0$ and farmers; $\bar{x}=3.0$ ), participation and coordination of agriculture development projects and programmes at local levels (LG staff; $\bar{x}=3.9$ and farmers; $\bar{x}=3.0$ ) among others. However, extension services were not offered in the study area according to interview with HODs of some agricultural/veterinary departments of some LGs. Okafor (2007) reports that LGs provided extension services during the implementation of R-Box Initiative. However, Nwalieji, Igbokwe and Nsoanya (2012) report that LG staff agreed that provision of agricultural extension and provision of animal health extension services roles were accomplished to a great extent by LGAs in Anambra State. These roles increased the effectiveness of some agricultural projects such as Fadama Projects and interventions such as Committee on Cassava Production and Export and R-Box (rice box) Projects etc. These findings are in agreement with Mojekwu (2012) and Okafor (2007) who report that the LGAs assisted in Fadama I, II and III Projects by providing training facilities at LG and farmers' levels, assisting in defraying local transport and travel costs, etc. and implementation of Cassava Production and Export Initiative of 2002.

All role presented in Table 2 were achieved as indicated by LG staff. Going by the report of the LG staff, most of the roles prescribed by the Nigerian Agricultural Policy of 2001 and the other roles contained in the constitution and amendments were accomplished by the LGAs. However, according to the observations of the farmers who are direct beneficiaries of agricultural roles of LGs, out of 29 roles that the LGs were supposed to perform, only nine were achieved and others were unaccomplished. This study shows that LGs are still inactive in their role achievement. This will negatively affect the stakeholder farmers in the study areas. Ejekwumadu (2009) reports that many of the LGAs cannot show any meaningful projects executed between 1999 to date notwithstanding the monumental inflow of allocations from the federal government. 


\section{Table 2: Perception of LG agriculture/veterinary staff and farmers on role} achievement of LG agricultural programmes

\begin{tabular}{|c|c|c|c|c|}
\hline \multirow[t]{2}{*}{ Role } & \multicolumn{2}{|c|}{ LG staff } & \multicolumn{2}{|c|}{ Farmers } \\
\hline & $\overline{\bar{x}}$ & S.D & $\overline{\bar{x}}$ & S.D \\
\hline Provision of agricultural extension services & $4.0^{*}$ & 1.0 & $3.1^{*}$ & 1.2 \\
\hline Provision of animal health extension services & $3.9^{*}$ & 1.1 & $3.0^{*}$ & 1.7 \\
\hline Control and acquisition of land for new entrants into farming & $3.6^{*}$ & 1.5 & 2.5 & 1.7 \\
\hline Provision of road network or good feeder roads & $4.2^{*}$ & 0.9 & $3.1^{*}$ & 1.7 \\
\hline Provision of processing plants & $3.7^{*}$ & 1.3 & 2.1 & 1.8 \\
\hline Provision of storage facilities & $3.8^{*}$ & 1.3 & 2.0 & 1.8 \\
\hline Provision of water scheme-borehole & $4.1^{*}$ & 1.0 & 2.3 & 1.9 \\
\hline Provision of veterinary clinics & $3.8^{*}$ & 1.3 & 2.7 & 3.1 \\
\hline Provision of markets & $4.0^{*}$ & 1.1 & 2.7 & 2.0 \\
\hline Provision of slaughter houses and slabs & $4.3^{*}$ & 4.7 & 2.8 & 1.9 \\
\hline Provision of market gardens & $3.6^{*}$ & 1.3 & 2.6 & 3.7 \\
\hline Establishment of demonstration plots & $3.7^{*}$ & 1.2 & 2.3 & 1.9 \\
\hline $\begin{array}{l}\text { Mobilization of farmers for cooperatives and formation of } \\
\text { farmer communities associations }\end{array}$ & $4.4^{*}$ & 3.5 & $3.0^{*}$ & 1.7 \\
\hline \multicolumn{5}{|l|}{ Procurement and distribution of agricultural inputs : } \\
\hline Provision of fertilizers & $4.2^{*}$ & 1.1 & $3.2^{*}$ & 4.7 \\
\hline Agro-chemicals such as herbicides, etc. & $4.0^{*}$ & 1.1 & 2.6 & 4.7 \\
\hline Improved seeds & $4.0^{*}$ & 1.1 & 2.6 & 4.5 \\
\hline Improved seedlings & $4.0^{*}$ & 1.1 & 2.6 & 4.6 \\
\hline Improved breeds of livestock & $3.8^{*}$ & 1.3 & 2.3 & 1.9 \\
\hline Provision of veterinary drugs and vaccines & $3.7^{*}$ & 1.3 & 2.4 & 1.8 \\
\hline Provision of tractors and implements & $3.7^{*}$ & 1.4 & 2.6 & 1.8 \\
\hline $\begin{array}{l}\text { Promotion of viable agro-based projects such as snail, fish, } \\
\text { poultry etc. farming }\end{array}$ & $4.2^{*}$ & 4.4 & 2.5 & 1.9 \\
\hline $\begin{array}{l}\text { Creation of awareness through exhibition of agricultural } \\
\text { products, shows, tree planting field days etc. }\end{array}$ & $4.0^{*}$ & 1.2 & $3.0^{*}$ & 1.8 \\
\hline $\begin{array}{l}\text { Participation and coordination of agriculture development } \\
\text { projects and programmes at local levels }\end{array}$ & $3.9^{*}$ & 1.1 & $3.0^{*}$ & 1.6 \\
\hline $\begin{array}{l}\text { Rural youth and women training on various agriculture } \\
\text { enterprises }\end{array}$ & $3.9^{*}$ & 1.2 & $3.0^{*}$ & 1.9 \\
\hline Provision of agriculture staff training and workshops & $3.9^{*}$ & 1.1 & $3.0^{*}$ & 2.0 \\
\hline Provision of health centres and clinics & $3.9^{*}$ & 1.1 & 2.6 & 2.1 \\
\hline Overall t-test & 3.9 & & 2.6 & \\
\hline
\end{tabular}

${ }^{*}=$ achieved roles $(\bar{x}=\geq 3.0)$

\section{Differences in perception of role achievement of LGAs in agricultural programmes between LG staff and farmers}

There were significant differences $(t=18.0 ; P \leq 0.05)$ in perception of $L G$ staff and farmers on the extent of achievement of all the roles presented (Table 3 ). 


\section{Table 3: Differences between staff and farmers on perception of role achievements of LGCs' agricultural/veterinary departments}

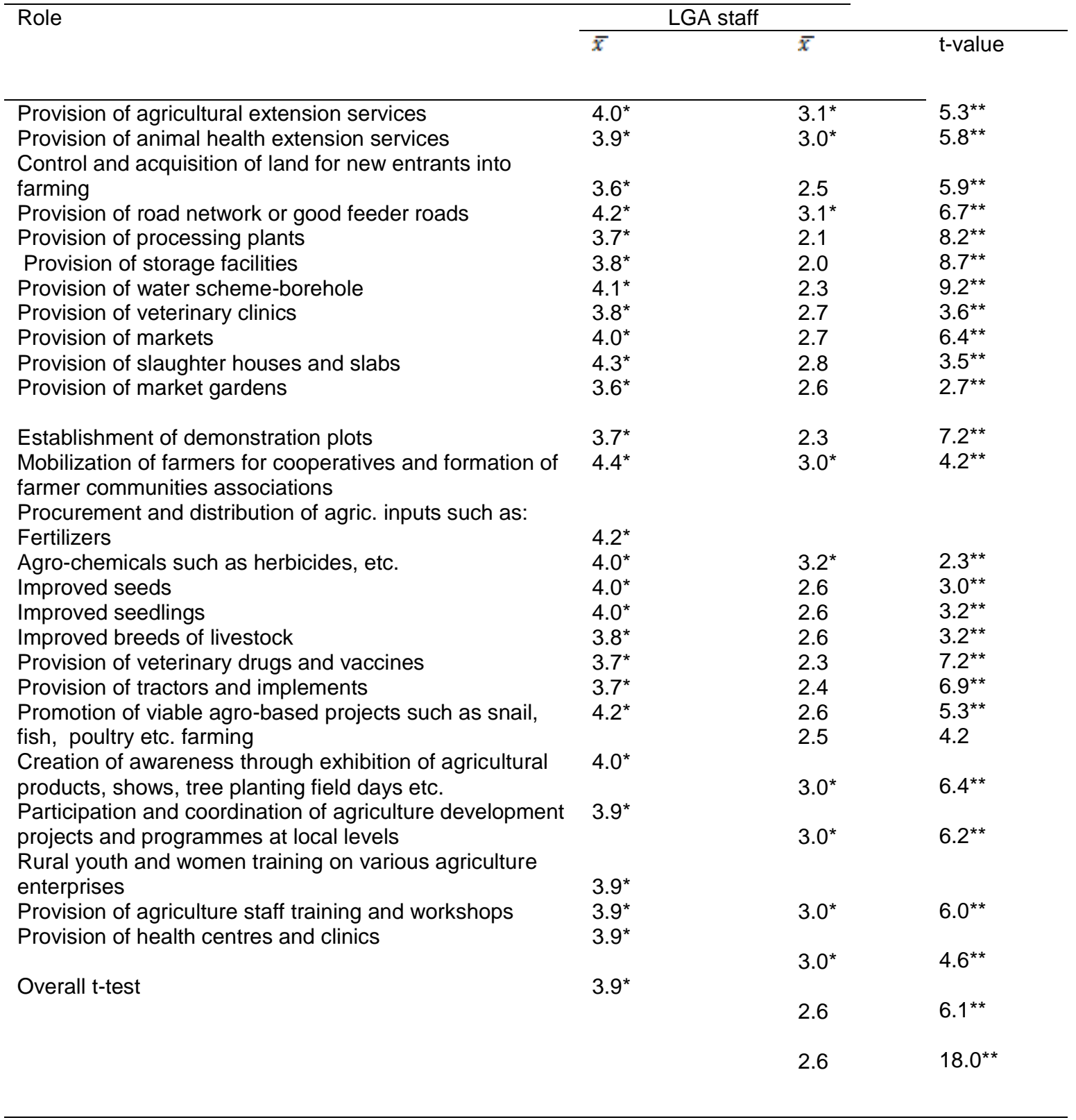

* =achieved $\operatorname{roles} \overline{(x}=\geq 3.0) ;{ }^{* *} \mathrm{P} \leq 0.05$

Specifically, significant differences were observed in provision of agricultural extension services $(\mathrm{t}=5.3 ; \mathrm{P} \leq 0.05)$, provision of animal health extension services ( $t=5.8 ; P \leq 0.05)$, control and acquisition of land for new entrants into farming ( $\mathrm{t}=5.9 ; \mathrm{P} \leq 0.05)$ among others. Farmers were not satisfied with role achievement of LGAs on agricultural development activities. Some authors 
(Isah, 2012, and Ejekwumadu, 2009), have expressed poor performance of LGAs in agricultural programmes which shows that farmers were more factual in their report. The LG staff were probably reluctant to expose their inefficiency.

\section{Conclusion}

The LGAs still perform many important agricultural roles without which agricultural production will even be much lower than what it is presently; examples include buying and distributing of bags of fertilizer to farmers, provision of staff to help pilot agricultural programmes such as National Programme for Food Security (NPFS), provision of counterpart funding of Fadama III Projects, etc. However, farmers found the level of LGAs' role achievement of agricultural programmes unacceptable. They believed that LGs perform below expectation towards achievement of many of their agricultural mandate which will negatively affect smallholder farmers in the study area. The perceptions of the two groups of respondents differ significantly on LGAs' agricultural role expectation and role achievement.

\section{Recommendation}

Based on the findings of the study, the following recommendations were made:

1. There should be representatives of farmers in LGs' Agriculture/Veterinary Department who will be involved in planning of agricultural interventions that will address farmers felt needs.

\section{References}

Akinsuyi, Y. (2011). Local government intervention: Impact in small scale farming. This day Live. Nigeria, pp. 4.13 December, 2011.www.thisdaylive.com (Accessed on $3^{\text {rd }}$ June, 2011).

Ejekwumadu, U. (2009). Burdens of local government administration in Nigeria. www.lg-working-papers.blogspot.com (Accessed on $3^{\text {rd }}$ June, 2011).

Isah, M. A. (2012). Motivation and local government employees in Nigeria. European Scientific Journal August Edition, vol. 8, (18), pp.129-141.

Madukwe, M. C. (2008). Role of local government in Fadama 111. Paper presented at workshop held at Abuja on $17^{\text {th }}$ September.

Manyong, V. M., A. Ikpi, J.K. Olayemi, S. A. Yusuf, B. T. Omonona, V. Okoruwa, and F. S. Idachaba (2005). Agriculture in Nigeria: Identifying opportunities for increased commercialization and investment. International Institute of Tropical Agriculture (IITA), Ibadan, Nigeria, pp. 50-57.

Mojekwu, C. (2012). Anambra State Fadama 111 Project: An overview. In: A. $O$. Aniebo and COA Ugwumba (editors). Proceedings of International Agricultural Conference ANSUIAC 2012 on Environmental concerns and 
agricultural productivity: addressing the challenges of food security, pp 20-23.

Nwalieji, H. U., Igbokwe, E. M. and Nsoanya, L. N. (2012). Role of Local Government in Agricultural Anambra State, Nigeria. . In: A. O. Aniebo and COA Ugwumba (eds.). Proceedings of International Agricultural Conference (ANSUIAC 2012) Environmental concerns and agricultural productivity: addressing the challenges of food security, pp. 71-78.

Okafor, L. C. (2007). Various laws, policies and reforms in the agricultural sector. A paper presented at a 3-day workshop for Agricultural Officers and Superintendents, Veterinary Officers organized by Anambra State Local Government Service Commission. 11 $1^{\text {th }}-13^{\text {th }}$ June, 2007 at Modotel, Enugu, pp. 8-12.

Okenwa, B. U. (2009). The role of local government food production, distribution and preservation. An invited paper at a three-day National Executive Workshop on 'Strategies for management of democratic dividends at the local governments. $10^{\text {th }}-12^{\text {th }}$ June, 2009, at Abuja. 